\title{
Inorganic markers profiling in wild type and genetically modified plants subjected to abiotic stresses
}

\author{
Mery Malandrino a , Agnese Giacomino ${ }^{\mathrm{b}, *}$, Mani Karthik ${ }^{\mathrm{c}}$, Isabella Zelano ${ }^{\mathrm{d}}$, Debora Fabbri ${ }^{\text {a }}$, Marco Ginepro ${ }^{\mathrm{a}}$, \\ Roger Fuoco ${ }^{\mathrm{e}}$, Patrizia Bogani ${ }^{\mathrm{f}}$, Ornella Abollino ${ }^{\mathrm{a}}$ \\ a Department of Chemistry, University of Torino, Via Giuria 5, 10125 Torino, Italy \\ b Department of Drug Science and Technology, University of Torino, Via Giuria 9, 10125 Torino, Italy \\ c Centre for Nanomaterials, International Advanced Research Centre for Powder Metallurgy and New Materials (ARCI), Balapur, Hyderabad 500005, India \\ d Le Centre de Recherches Pétrographiques et Géochimiques (CRPG), 15 Rue Notre Dame des Pauvres, 54500 Vandœuvre-lès-Nancy, France \\ e Department of Chemistry and Industrial Chemistry, University of Pisa, Via Moruzzi 3, 56124 Pisa, Italy \\ ${ }^{\mathrm{f}}$ Department of Biology, University of Florence, Via Madonna del Piano 6, 50019 Sesto Fiorentino, Italy
}

\section{A R T I C L E I N F O}

\section{Article history:}

Received 12 April 2017

Accepted 12 April 2017

Available online 14 April 2017

\section{Keywords:}

Nicotiana transgenic plants

Rat glucocorticoid receptor

rolC

Inorganic stress markers

Chemometrics

\begin{abstract}
A B S T R A C T
Nicotiana is a well characterized genus of Solanaceae. It is widely studied in literature in different research fields, such as biology, environmental chemistry, etc. In this study Nicotiana langsdorffii wilde type plants and transgenic for the rat glucocorticoid receptor gene (GR) or Agrobacterium rhizogenes rolC gene were used to value the effect of exposure to chemical compounds $(\mathrm{Cr})$ and to harsh physical conditions (dryness, heat stress) on the inorganic compositions in plants. Four markers were selected, namely $\mathrm{Na}, \mathrm{K} \mathrm{Cl}^{-}$and $\mathrm{NO}_{3}^{-}$. Different procedures of extraction were tested: water permitted to obtain the best conditions for the determination of four selected markers. The analysis was carried out by atomic emission spectroscopy for the determination of the cations; the anions were determined both by ion chromatography and potentiometry: the results obtained by these two techniques and their potentiality were compared. The total cation content ( $\mathrm{Al}, \mathrm{Ca}, \mathrm{Cr}, \mathrm{Fe}, \mathrm{K}, \mathrm{Mg}$, Mn, Na, P, Si and $\mathrm{Zn}$ ) was also determined. The effect of the genetic modifications on the capacity of the plant to contrast the stress stimuli was valued: the introduction of GR gene seems to greatly reduce the effect caused by the stresses and the adsorption of the inorganic pollutants. The modification with rolC increases the absorption capacity of the plant toward $\mathrm{Cr}$ and at the same time reduces its release: this behavior can be exploited in phytoremediation applications.
\end{abstract}

(c) 2017 Elsevier B.V. All rights reserved.

\section{Introduction}

In the case of plants, we can define "stress" as "a strength that tends to show an influence on the natural mechanism of its functioning" [1]. For example, extreme environmental phenomena such as droughts cause conditions of stress for plants with a significant impact on their physiology, morphology and development [2].

Plants exposed to biotic and abiotic stresses respond with various biochemical reactions to protect themselves against the causal agent [1]: the action of stresses can induce, within the vegetal organisms, the production of compounds able to contrast the effects of the attack [3,4].

Abiotic stresses can be classified in i) hydric (drought or flooding); ii) thermal (heating or chilling/freezing); iii) saline (salinity); iv) mineral (deficiency or excess); v) mechanic (brushing or restriction). Another classification of abiotic stresses can be: i) physical, such as lack of water or presence of extremely high or low temperatures, or ii) chemical, in case of exposure to toxic species.

\footnotetext{
* Corresponding author.

E-mail address: agnese.giacomino@unito.it (A. Giacomino).
}

In particular, in the case of water deficit, which can be due to drought, cold or osmotic shock, an accumulation of various molecular compounds, such as proline, glutamate, glycine-betaine, carnitine, mannitol, sorbitol, fructans, threalosium, saccharosium and oligosaccharides within the plant cells was observed: it is believed that this effect is due to an increase of osmotic pressure inside the cells and to an higher retention of water. Furthermore, with the aim of maximizing water retention, an increase in the production of abscissic acid takes place, with a consequent closure of stomes [5].

Thermal stress at high temperature is caused by the exposure of plants to a temperature higher than that of maximum growth for long or short periods. Most plants are not able to survive at temperatures higher than $45^{\circ} \mathrm{C}$, with a few exceptions as some Mediterranean and tropical species $\left(48-55^{\circ} \mathrm{C}\right.$ ) and some woody subtropical plants $(50-$ $60^{\circ} \mathrm{C}$ ). Independently of the capacity of surviving at high temperature, the stress condition starts above $30{ }^{\circ} \mathrm{C}[6]$.

It is well known that the presence of high concentrations of heavy metals can cause some of the most severe damages to plants. Most metal ions are essential in the maintenance and evolution of all living systems, and also mediate all stages of dissemination of genetic 
information carried in the genetic code. On the other hand, essential metals, when present in excess can produce errors in the genetic information system and/or cause serious damages to plants or even their death. In particular, these detrimental effects are exerted by metals which have no biological roles, such as $\mathrm{Cd}$ and $\mathrm{Pb}$, when present above certain limits of concentration. The amount of a metal absorbed by plants from soil depends on its concentrations and speciation in the soil solutions, its translocation from the bulk soil to the root surface, then into the root and finally into the shoot and leaves. The same uptake processes take place both for essential micronutrient cations and non-essential metal ions.

Excessive concentrations of metals result in phytotoxicity through: i) changes in the permeability of the cell membrane; ii) reactions of sulphydryl (-SH) groups with cations; iii) affinity for reacting with phosphate groups and active groups of ADP or ATP; and iv) replacement of essential ions [4,7]. Several plant species developed tolerant variants that can survive on metal-contaminated environment through adaptation [8].

The knowledge of the possible response to different stresses can be helpful i) to understand the physiology and the biochemistry of plants, ii) to identify methodologies and techniques suitable to reduce the stress effect on their growth and production and iii) to select stress-resistant cultivars.

The effect of both biotic and abiotic stresses can be assessed by monitoring the variation of the in-cell levels of different phytoregulators produced by the plants for their defense. Among these, phytohormones are the most extensively studied in literature, because they exert remarkable effects on the processes of growth and development of plants such as germination, foliar expansion and flower development [9-12]. Also some inorganic species represent important indicators of stress in vegetation. In particular the content of alkali metals, namely sodium and potassium, and inorganic anions, such as chlorides and nitrates, changes as a consequence of stress. For example, $\mathrm{K}^{+}, \mathrm{Na}^{+}$and $\mathrm{Cl}^{-}$are nutrients that remain as ions in the plant tissues. $\mathrm{K}^{+}$is required as cofactor from more than forty enzymes and has an essential role in the maintenance of cellular turgidity and electroneutrality. $\mathrm{Cl}^{-}$is required in the photosynthetic reactions for the generation of $\mathrm{O}_{2}$. $\mathrm{Na}^{+}$is involved in the generation of phospoenolpiruvate and can substitute $\mathrm{K}$ in some functions. $\mathrm{N}$ is a constituent nutrient of many organic vegetal components: amino acids, amides, proteins, nucleic acids, nucleotides, coenzymes and esammines. Plant-available inorganic forms of $\mathrm{N}$ include nitrate $\left(\mathrm{NO}_{3}\right)$ and nitrite $\left(\mathrm{NO}_{2}\right)$, as well as ammonium $\left(\mathrm{NH}_{4}\right)$ [13]. The variation in their concentration as a consequence of abiotic stress is due to the fact that such ions have an important role in the transport of matter within plants and in osmoregulation. While a lot of papers are available in literature about phytohormones, very few papers pertain to these species [14-16].

In this paper, we have compared the changes of the inorganic markers pattern in a model plant system, namely Nicotiana langsdorffii wild type plants and transgenic for the rat glucocorticoid receptor gene (GR) or transgenic for the Agrobacterium rhizogenes rolC gene, after $\mathrm{Cr}(\mathrm{VI})$ exposure, scarcity of water and high temperature. This system has been used in previous studies for the analysis of different stressinduced effects. Data on changes in hormonal endogenous content are reported in Fuoco et al. [17], while changes in sugars and phenolic compounds or heavy metals accumulation are showed by Del Bubba et al. [18] and Ancillotti et al. [19]. A deep analysis of metabolomic patterns $[20]$ and changes in terpenoids and ionomic profiles $[21,22]$ were also reported. In this paper we obtained new data both on the effects of different stresses and of the presence of a genetic modification on the plant response. In addition to the selected markers, namely $\mathrm{Cl}^{-}, \mathrm{NO}_{3}^{-}, \mathrm{K}^{+}$and $\mathrm{Na}^{+}$, the concentrations of $\mathrm{Cr}$ and of other elements ( $\mathrm{Al}, \mathrm{Ca}, \mathrm{Fe}, \mathrm{Mn}, \mathrm{Si}, \mathrm{P}$ and $\mathrm{Zn}$ ) were determined. The data were treated with chemometric techniques to better value the effect of the different stresses on the considered plants. Moreover, this work provides a complete optimised protocol for plant treatment and analysis for the determination of these types of analytes.

\section{Materials and methods}

\subsection{Plant material and sample pretreatment}

Nicotiana langsdorffii plants, wild type and transgenic for rat glucocorticoid receptor gene (GR) or Agrobacterium rhizogenes rolC gene, were analysed.

Plant modification, incubation and growth were carried out at the former Department of Evolutionary Biology "Leo Pardi” (now Department of Biology), University of Florence, by Prof. M. Buiatti and Dr. P. Bogani. The modified plants were obtained and characterized following the procedure described elsewhere $[19,23,24]$.

The examined plants can be considered as a homogeneous material with the exception of the presence of a gene in the modified plants, that changes the hormonal equilibrium. The plant specimens were grown in controlled and reproducible conditions. Cultures were incubated in a growth chamber at $24 \pm 1{ }^{\circ} \mathrm{C}$ with a photoperiod of $16 \mathrm{~h}$ of light (1500 lx) and 80\% relative humidity. After germination, seedlings were grown on LS (Linsmaier and Skoog) medium for one month.

\subsection{Apparatus and reagents}

Sample dissolution for the determination of total metal concentrations was performed in polytetrafluoroethylene PTFE bombs, with a Milestone MLS-1200 Mega (Milestone, Sorisole, Italy) microwave laboratory unit.

The cations were determined with a Perkin Elmer Optima 7000 (Perkin Elmer, Norwalk, Connecticut, USA) inductively coupled plasma-optical emission spectrometer (ICP-OES). The anions were determined by a DX-500 (Dionex, Sunnyvale, CA, USA) ion chromatograph (IC) equipped with a conductometric detector (ED40, Dionex), using an Ion Pack AS9-HC anion exchange column. The results were compared with those obtained analysing the same extracts by a Metrohm potentiometer equipped with combined Ion Selective Electrodes, ISE (Thermo Fisher Scientific, the Netherlands).

Analytical grade reagents were used throughout. Standard metal solutions were prepared from concentrated Merck Titrisol stock solutions (Merck, Darmstadt, Germany).

High purity water (HPW) obtained from a Milli-Q apparatus (Millipore, Bedford, USA) was used throughout for the preparation of sample and standard solutions.

\subsection{Procedures}

\subsubsection{Stress exposure}

2.3.1.1. Chemical stress (CS). The concentration of $\mathrm{Cr}$ for the induction of metal stress in plants was selected on the basis of preliminary experiments aimed at testing the lethal-dosage 50 (LD50) on survival and callus formation capacity of leaf tissues of wild type $N$. langsdorffii plants grown in vitro. The standard working solutions were prepared from potassium dichromate $\left(\mathrm{K}_{2} \mathrm{Cr}_{2} \mathrm{O}_{7}\right)$ concentrated standard solutions (Merck Titrisol).

Working solutions were filter-sterilised by $0.22 \mu \mathrm{m}$ Millipore membrane filters and a suitable volume was added to the LS culture medium to have a concentration of $50 \mathrm{ppm}$. The complete procedure is described in the paper by Fuoco et al. [17].

2.3.1.2. Drought stress (DS). Polyethylene glycol (PEG) was added to dehydrate the LS medium (described in Bogani et al. [24]). PEG is widely used to modify the osmotic potential of nutrient solution cultures and to induce plant water deficit in a relatively controlled manner, appropriate to experimental protocols. It was assumed that PEG of large molecular weight does not penetrate the plant and thus is an ideal osmoticum for use in hydroponics root medium [25]. The concentration of PEG for the induction of drought stress was evaluated by a dose/effect curve 
experiment conducted on leaf discs of wild type and transgenic $N$. langsdorffii. In particular, 60 leaf discs per genotype were added to each Petri dish containing approximately $20-25 \mathrm{ml}$ of solidified LS $+1 \mathrm{mg} / \mathrm{l}$ BAP (6-benzylaminopurine), $0.1 \mathrm{mg} / \mathrm{l} \mathrm{NAA}$ (1-naphthaleneacetic acid) and $20 \mathrm{ml}$ of $0 \%$ or $5 \%$ or $10 \%$ or $20 \%$ PEG 6000 . After 24 h the PEG solution was removed in accordance with the method described in van der Weele et al. [26], and sample growth capacity (callus induction) and regeneration (induction of shoots) was evaluated. The results of the experiments indicate that the ability of growth of non-transformed $N$. langsdorffii is strongly inhibited by a concentration of PEG $20 \%$ and that the regeneration capacity is drastically reduced already at a PEG concentration of 5\%. Surprisingly, the explants of transgenic plants, and particularly those obtained from the transgenic plants for the GR receptor, are more resistant to treatment with 20\% PEG. On the basis of these results, a PEG concentration of $20 \%$ was used for the assessment of the effects of response to water stress. For this purpose, 50 plants of $N$. langsdorffii wild type and transgenic for GR or rolC gene were maintained on LS culture medium containing 20\% PEG for two weeks before being analysed along with the corresponding not exposed controls.

2.3.1.3. Heat stress (HS). Since most plants are not able to survive at temperatures higher than $45^{\circ} \mathrm{C}$ and the stress condition starts above $30{ }^{\circ} \mathrm{C}$ [6], the heat stress was induced on 50 plants of $N$. langsdorffii wild type and transgenic for GR or rolC gene in LS culture medium by maintaining the samples at $50{ }^{\circ} \mathrm{C}$ for $2 \mathrm{~h}$ in an incubator. At the end of the period the samples were immediately frozen with liquid nitrogen and analysed along with the corresponding not exposed controls.

\subsubsection{Sample pretreatment}

The samples were frozen with liquid nitrogen if not already frozen and immediately grinded in a mortar in order to obtain a powdered sample. Then, they were freeze-dried and a recovery of $5 \pm 0.5 \%$ was obtained for all samples. The results reported are referred to the freeze-dried samples.

\subsubsection{Extraction of anions and cations}

Three procedures were selected among the different ones available in literature regarding the extraction of anions from vegetables. These procedures were preliminarily tested on lettuce plants purchased from a local market to value the extraction efficiency for the considered inorganic markers. The tested procedures were:

Procedure A: the sample was cut into small pieces of about $1 \mathrm{~cm}$. A $1.5 \mathrm{~g}$ aliquot was weighed, suspended in $500 \mathrm{ml}$ of high purity water (HPW), and homogenized for $1 \mathrm{~min}$ [27-29].

Procedure B: a $10 \mathrm{~g}$ aliquot of sample was added with $50 \mathrm{ml}$ of $200 \mathrm{mM}$ sodium borate solution heated at $80^{\circ} \mathrm{C}$. The sample was brought to $100 \mathrm{ml}$ with sodium borate solution, heated again at $80^{\circ} \mathrm{C}$ for $15 \mathrm{~min}$, and finally cooled [30].

Procedure C: a $0.5 \mathrm{~g}$ aliquot of sample was shaken with $25 \mathrm{ml}$ of $2 \%$ $(\mathrm{v} / \mathrm{v})$ acetic acid for $30 \mathrm{~min}$ on an oscillating rolling-bed shaker [31].

In all cases, the suspensions obtained were centrifuged for $5 \mathrm{~min}$, filtered through a $0.45 \mu \mathrm{m}$ cellulose acetate filter and conveniently diluted for anion and cation determinations.

Taking into account the preliminary results on the lettuce plant, HPW was chosen as extractant for the analysis of Nicotiana samples (see Section 3.3) following the conditions specified in procedure $C$. The solutions obtained were diluted to 1:20 and 1:200 with water for the determination of cations and anions respectively.

All experiments were performed in triplicate.

\subsubsection{Total cation content}

The total concentrations of cations were determined after acid digestion in microwave oven, treating aliquots of $0.2 \mathrm{~g}$ of each sample with $6 \mathrm{ml}$ of a mixture of $\mathrm{HNO}_{3}: \mathrm{H}_{2} \mathrm{O}_{2}=1: 1$. After the digestion, the solutions were filtered through Whatman 5 filters and diluted with HPW to $50 \mathrm{ml}$. The final solutions were analysed by ICP-OES.
Since the plant dissolution requires the use of nitric acid that would obviously add a great amount of $\mathrm{NO}_{3}^{-}$ions to the sample solutions, the total concentration of anions was not determined.

\subsubsection{Sample analysis}

Water extracts were analysed using IC and potentiometry for the determination of anions. Analyte concentrations were quantified by the standard addition technique.

The eluent used during IC determination consisted of a mixture of $10 \mathrm{mM} \mathrm{K} \mathrm{CO}_{3} / 4 \mathrm{mM} \mathrm{NaHCO} 3(90 \%)$ and $\mathrm{HPW}$ (10\%) and was run through the system at a flow rate of $1 \mathrm{ml} / \mathrm{min}$.

Potentiometric determinations of anions were conducted in the presence of total ionic strength adjustment buffer solution, $0.06 \mathrm{M} \mathrm{KNO}_{3}$ and $0.1 \mathrm{M}\left(\mathrm{NH}_{4}\right)_{2} \mathrm{SO}_{4}$ for $\mathrm{Cl}^{-}$and $\mathrm{NO}_{3}^{-}$determination respectively. To minimize the effect of the temperature, the solutions were stored at $25^{\circ} \mathrm{C}$ until the measurement; the signal rapidly reached a stable value (10 s), and the electrode was carefully washed with HPW after each measurement.

The water extracts and the digested solution were analysed by ICPOES for the determination of cations.

Three replicates were performed and blanks were simultaneously run. Standard solutions for instrument calibration were prepared in the corresponding blank, according to the matrix-matching technique.

The following wavelengths were selected for the determination of $\mathrm{Na}, \mathrm{K}, \mathrm{Cr}$ and other elements: $\lambda_{\mathrm{Al}}=396,153, \lambda_{\mathrm{Ca}}=317,933, \lambda_{\mathrm{Cr}}=$ $267.716, \lambda_{\mathrm{Fe}}=259,939, \lambda_{\mathrm{K}}=769.896, \lambda_{\mathrm{Mg}}=285,213, \lambda_{\mathrm{Mn}}=257.61$, $\lambda_{\mathrm{Na}}=589.592, \lambda_{\mathrm{P}}=213,617, \lambda_{\mathrm{Si}}=251,611, \lambda_{\mathrm{Zn}}=213,857 \mathrm{~nm}$.

\subsubsection{Chemometric data processing}

A chemometric analysis of the experimental results was performed by principal component analysis (PCA), with the aid of an XLStat 7 software package, used as a Microsoft Excel plug-in. Unscrambler X 10:2 was also employed for data standardization, obtained by mean-centering (for each variable) and dividing by the corresponding standard deviation, and for substituting values below LoQs with estimated values. Analytes with most values below the LoQ were not included. For the principles of the technique, the reader is referred to existing textbooks and papers on chemometrics $[32,33]$.

\section{Results and discussion}

\subsection{Plants appearance}

The transformation of $N$. langsdorffii plants with both $G R$ gene and rolC gene induced significant differences in both morphology and growth $[24,34]$. The exposure to the water stress due to the growth of plants for 15 days on LS medium containing 20\% PEG, induced a clear wilting effect only on untransformed plants, while GR and rolC transgenic plants did not show any stress symptom. Moreover, the wild type plants showed a significant decrease in both root and shoot biomass (dry weight data), whereas only a decrease of root biomass in GR plants and no difference of biomass data in rolC plants was observed. The exposure of plants to $50{ }^{\circ} \mathrm{C}$ for $2 \mathrm{~h}$ did not affect the plant appearance in the three types of plants. However a different re-growth capability was observed in transgenic plants, compared to the untransformed ones, when the plants were grown for three weeks at $25^{\circ} \mathrm{C}$ (the optimal growth temperature), after the heat treatment. These data suggested a higher tolerance to stress condition due to the insertion of transgenes [19].

\subsection{Total cation contents}

Nicotiana langdorffii was not grown in soil, so the only sources of metals and of inorganic species is the growth medium and, at a much lesser extent, atmospheric deposition or impurities present in the water used for irrigation. A preliminary semiquantitative analysis of the plant extract showed the presence of quantifiable amounts of $\mathrm{Al}$, $\mathrm{Ca}, \mathrm{Fe}, \mathrm{Mg}, \mathrm{Mn}, \mathrm{P}, \mathrm{Si}$ and $\mathrm{Zn}$ : we determined the concentrations of 
these elements, in addition to those of the markers ( $\mathrm{Na}$ and $\mathrm{K}$ ) and of the added pollutant $(\mathrm{Cr})$, to obtain further information on the changes of chemical composition of the plants after the applied treatments.

Table 1 reports the contents (expressed in $\mathrm{g} / \mathrm{kg}$ ) of the cations in the digested solutions. The most abundant element is $\mathrm{K}(66 \div 221 \mathrm{~g} / \mathrm{kg})$, followed by the other macronutrients, namely P $(4.65 \div 14.9 \mathrm{~g} / \mathrm{kg})$, Ca $(4.38 \div 7.39 \mathrm{~g} / \mathrm{kg})$ and $\mathrm{Mg}(1.10 \div 2.48 \mathrm{~g} / \mathrm{kg})$; as to micronutrients, $\mathrm{Na}$ ranges between 0.48 and.78 g/kg, whereas $\mathrm{Al}, \mathrm{Fe}, \mathrm{Mn}$, Si and Zn contents are always lower than $0.4 \mathrm{~g} / \mathrm{kg}$.

We observed remarkable differences among the unstressed plants; in particular, WT samples contained the highest concentration values for K, $\mathrm{Mg}, \mathrm{Mn}, \mathrm{P}$ and Si, while rolC-modified specimens generally presented the lowest amounts of these cations. WT and GR contain 0.97 and $1.15 \mathrm{~g} / \mathrm{kg}$ of Na respectively, while the concentration of this element in rolC is about half of this value. These results show how the genetic modifications are able to change the natural inorganic content in Nicotiana langsdorfii. We can observe that Ca concentration does not present a particular trend, as confirmation of the fact that this element cannot be considered as a good marker for this type of studies; in fact, Taiz et al. [6] underline that after any type of modification or variation it moves to different parts of the plant, but its total amount remains quite constant.

All the considered stresses cause a decreasing in K concentration both in the wild type and the modified plants. In particular the heat stress has the strongest effect, causing a $65 \pm 3 \%$ loss of this element in all the plants. In dryness condition the plants naturally tend to increase the adsorption of $\mathrm{K}$ and other elements from the soil to maintain the osmoregulation [6]. It is a strategic response of the plant to survive, since storing solutes in the cells helps maintaining a positive turgidity pressure that is required to the cell expansion, even in the presence of a low hydric potential. The opposite trend in K concentration found in our study is probably due to the fact that the Nicotiana specimens were grown in vitro.

For Na we can observe as the presence of stress causes a decrease in its concentration in WT plants, while heat stress causes an increasing of $\mathrm{Na}$ content in GR and rolC-modified plants; in the case of rolC, also $\mathrm{Cr}$-stress causes an increasing of Na concentration. Plants have evolved mechanisms to regulate $\mathrm{Na}$ accumulation and to select against it in favor of other nutrients as $\mathrm{K}^{+}$and $\mathrm{NO}_{3}^{-}$. For example, in most plants $\mathrm{Na}^{+}$and $\mathrm{Cl}^{-}$are effectively excluded by roots while water is taken up from highly salinity soils [34]. In the presence of physical stresses that can cause a metabolic disorder the stomes would not be able to expel it. For this reason, we expected higher levels of $\mathrm{Na}$ in the presence of stressful conditions as observed in the cases underlined for the modified plants.

The chemical stress induced by the presence of a pollutant, as $\mathrm{Cr}$, causes phenomena of antagonism among the cations, giving rise to a decreasing of the concentration of the elements naturally present in the plants: this behavior was observed both for $\mathrm{K}$ and $\mathrm{Na}$, with the only exception of $\mathrm{Na}$ in rolC. As expected, the concentration of $\mathrm{Cr}$ dramatically increased after exposure of the plants to this element. The genetic modification with GR permitted to reduce the plant uptake toward this pollutant $(-21 \%)$, in comparison with WT samples. This result confirms the observation reported by Fuoco et al. [33]: they found that chromium did not exert any significant leaf biomass variation in GR-modified plants, denoting the resistance of this transgenic form to high $\mathrm{Cr}$ concentration; they associated these effects with the minor metal uptake compared to WT plants. On the contrary, the modification with rolC caused a greater absorption of $\mathrm{Cr}$ by Nicotiana ( $+42 \%$ ) in comparison with WT, in agreement with the results obtained by Del Bubba et al. [18].

Considering the total cation content, all the considered stresses cause its reduction in comparison with the unstressed plant. In particular the total cation content in the plants is more than halved in presence of heat stress.

\subsection{Extractable contents}

Three different extraction procedures were initially tested. Owing to the time required to obtain Nicotiana plants and the difficulties to

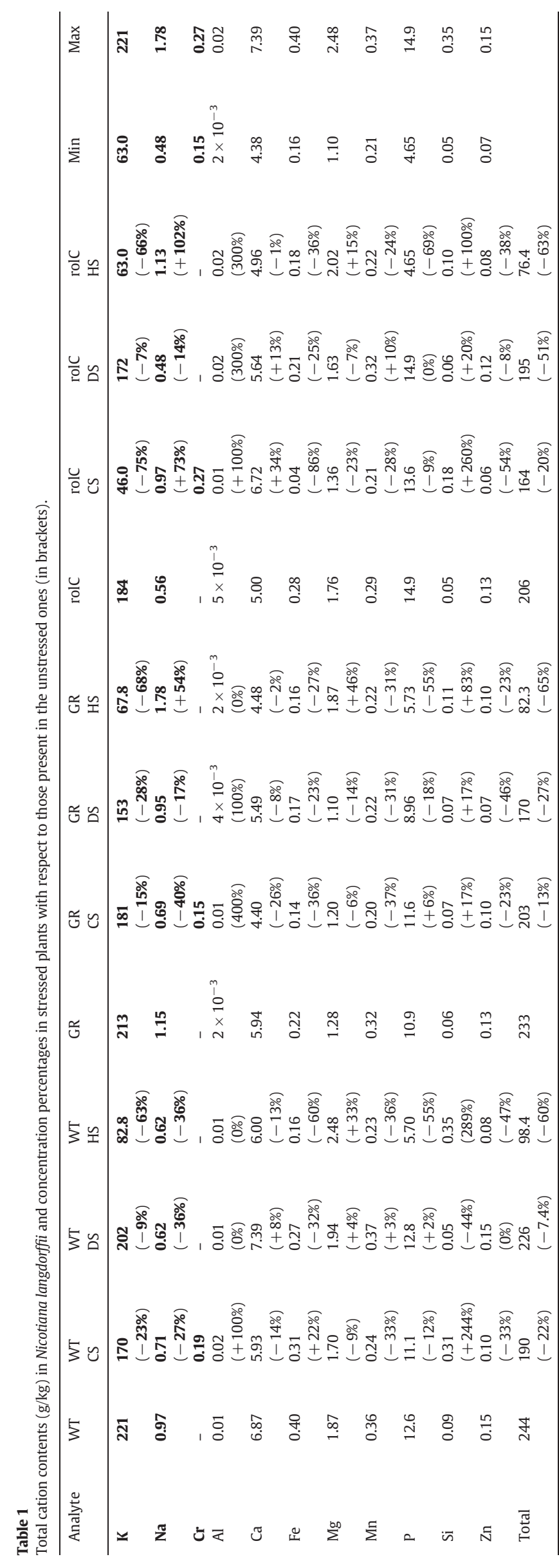


produce a sufficient amount of plants, these preliminary experiments were conducted on lettuce bought from a local market. Table 2 shows the results obtained in these experiments. Following the original procedures, the $\mathrm{C}$ one appeared as the most effective. Unfortunately, the presence of acetic acid gave some problems of reproducibility during the analysis by IC. Obviously, the use of sodium borate does not permit the determination of $\mathrm{Na}$. Then, the efficiency of the different extractants was compared using the same experimental conditions (amount of sample, volume of the extractant solution, contact time), as those reported in procedure $C$. Since the extraction yield did not significantly increase using the other two reagents in comparison to water, we chose HPW as extractant.

Water is largely used in literature for the extraction of anions from plants, also because it is the most suitable matrix for chromatographic techniques [27-29,35].

Before treating the samples of Nicotiana, we also valued the effect of the contact-time between the plant and water on the efficiency of the extraction. During the stirring, every $20 \mathrm{~min}$, an aliquot of the suspension was taken and analysed. The concentrations of all the markers in the extract increased until $120 \mathrm{~min}$, then remained constant: so we chose $120 \mathrm{~min}$ as the best extraction time. We underline that the aim of this study is not to extract the maximum amount of elements chosen as markers, but to compare the behavior of the markers in the considered plants.

\subsubsection{Extractable cation contents}

The concentrations ( $\mathrm{g} / \mathrm{kg}$ ) of $\mathrm{Ca}, \mathrm{Cr}, \mathrm{K}, \mathrm{Mg}$, Mn, Na, P and $\mathrm{Zn}$ found in the water extracts are reported in Table 3 . Since the total element content greatly varies among the considered plants, for a better interpretation of the data we also report the percentages of extraction with respect to the total content.

Generally, the percentages of extraction for the same analyte from different plants and for different analytes from the same plant are quite variable (from 7 to $21 \%$ for Ca, from 23.6 to $63.7 \%$ for $\mathrm{Mg}$, from 15.6 to $100 \%$ for $\mathrm{Mn}$, from 28.9 to 100 for Na, from 27.1 to 100 for P and from 19.8 to $66.5 \%$ for $\mathrm{Zn})$.

$\mathrm{Al}$, Fe and Si concentrations were very close to the instrumental detection limit in all samples.

Comparing the unstressed plants, $\mathrm{K}, \mathrm{Na}, \mathrm{Al}, \mathrm{Ca} \mathrm{Fe}, \mathrm{Zn}$ are released in higher extent from WT samples. A particular behavior is observed for $\mathrm{Mn}$ and $\mathrm{P}$, quantitatively extracted from rolC.

Even if the total and the extracted amounts of K are very variable, the percentage of extraction of $\mathrm{K}$ is comprised in the range 12-19 for all the samples, with the exception of the stressed rolC plants, in which this

Table 2

Marker concentrations $(\mathrm{g} / \mathrm{kg})$ found in lettuce extracts following procedures A, B and C and using the same procedure for all the extractants.

\begin{tabular}{|c|c|c|}
\hline Marker & $\begin{array}{l}\text { Concentration }(\mathrm{g} / \mathrm{kg}) \text { obtained } \\
\text { following the specific procedure } \\
(\mathrm{A}, \mathrm{B} \text { or } \mathrm{C})\end{array}$ & $\begin{array}{l}\text { Concentration }(\mathrm{g} / \mathrm{kg}) \text { obtained } \\
\text { following the same procedure }\end{array}$ \\
\hline & HPW (procedure A) & HPW \\
\hline $\mathrm{Cl}^{-}$ & 13.7 & 7.23 \\
\hline $\mathrm{NO}_{3}^{-}$ & 53.2 & 35.7 \\
\hline $\mathrm{Na}$ & 1.14 & 1.19 \\
\hline \multirow[t]{2}{*}{ K } & 48.4 & 39.8 \\
\hline & Sodium borate (procedure B) & Sodium borate \\
\hline $\mathrm{Cl}^{-}$ & 0.98 & 8.25 \\
\hline $\mathrm{NO}_{3}^{-}$ & 3.50 & 40.6 \\
\hline $\mathrm{Na}$ & - & - \\
\hline \multirow[t]{2}{*}{ K } & 3.47 & 41.2 \\
\hline & Acetic acid (procedure C) & Acetic acid \\
\hline $\mathrm{Cl}^{-}$ & 8.47 & 7.01 \\
\hline $\mathrm{NO}_{3}^{-}$ & 40 & 35.2 \\
\hline $\mathrm{Na}$ & 7.50 & 4.83 \\
\hline K & 53.70 & 35.0 \\
\hline
\end{tabular}

a $0.5 \mathrm{~g}$ of sample $+25 \mathrm{ml}$ of extractant solution. Contact time: $2 \mathrm{~h}$. element is little released. Heat stress caused a decrease in the release of this metal in all the plant types, in particular for the GR-modified one. We can observe that, while the presence of any type of stress causes the halving of the Na content in WT and GR, in rolC-modified plant the concentration of $\mathrm{Na}$ in unstressed specimens is similar and slightly lower than that found in the stressed plants.

Regarding the behavior of $\mathrm{Cr}$, while rolC presented the highest total concentration of this pollutant, it shows the lowest $\mathrm{Cr}$ content in the water extracts, demonstrating that this genetic modification causes a higher and stronger adsorption of this metal by the plant. This result can be useful in soil remediation studies to obtain more heavy metal-resistant plant, able to adsorb greater amount of pollutants from the soil and not easily releasing them into the environment. It is well know that rolC is capable of inducing root development in different plants [36-38]; this effect could be used to improve the capability of selected vegetals to immobilize pollutants possibly present in contaminated soils. Also Nair et al. [39] cloned a secondary Ni-Co transporter (NiCoT, TC 2.A.52) from Rhodopseudomonas palustrisvector into plant expression vector and introduced it into Nicotiana tabacum, demonstrating the potential of this transgenic plant to remediate cobalt from contaminated soils.

As to the other elements, no particular trends are observed. Only for WT, we can see that all applied stresses cause a decrease in the percentage of release, with the only exceptions of Mg and P in WT DS.

\subsubsection{Anion contents}

The content of $\mathrm{NO}_{3}^{-}$and $\mathrm{Cl}^{-}$in the water extracts was determined using IC and potentiometry. We chose to use IC results for data interpretation, since this technique is widely accepted as a suitable method for the determination of anions in environmental samples and is less prone to interferences. The results obtained with the two analytical techniques are compared in Section 3.3.3.

Table 4 reports the concentrations found in the water extracts and Fig. $1 \mathrm{a}$ and $\mathrm{b}$ show the trends of $\mathrm{Cl}^{-}$and $\mathrm{NO}_{3}^{-}$respectively, obtained with the two adopted techniques.

Among the unstressed plants no significant differences were present in the concentration of anions ${ }^{-}$in WT and modified specimens.

Regarding the effect caused by the considered stresses, a common trend was observed: the concentrations of the anions decreases in presence of any type of stress. Chemical stress causes a very similar $(-43 \div$ $-48 \%$ ) reduction in the extractable anions in all the plants, with the exception of $\mathrm{Cl}^{-}$extracted from GR-CS plant, which is extracted at a lower extent $(-23 \%)$.

Heat stress causes a substantial decrease $(>50 \%)$ of the extractable $\mathrm{Cl}^{-}$from all the plants, while we observe low effect on $\mathrm{NO}_{3}^{-}$. Water deficit gives rise to the most relevant reduction $(>80 \%)$ of the extractable anions in the wild type-plants; both the genetic modifications, in particular that with GR, reduce this effect.

Usually, $\mathrm{Na}$ and $\mathrm{Cl}$ present a similar behavior, that is their concentration increase and decrease at the same time, both in unstressed and stressed conditions. For example, because $\mathrm{NaCl}$ is the most soluble and widespread salt, plants have evolved mechanisms to regulate its accumulation and to select against it in favor of other nutrients commonly present in the soil [34]. For this reason, we compared the results obtained for these two analytes (Fig. B1): we obtained a good correlation between their concentrations $\left(\mathrm{r}^{2}=0.8661\right.$ ), (after removing WT-DS, WT-HS and rolC from the data set).

\subsubsection{IC vs ISE}

The results obtained by IC and potentiometry were compared. The two techniques revealed the same trend in the concentrations of the considered anions with some differences in the quantification. The concentrations of $\mathrm{Cl}^{-}$found with ISE were generally higher than those determined by IC, with the only exception of WT extract. The mean concentrations of $\mathrm{Cl}^{-}$found in the unstressed plants (WT, GR and rolC) using IC and ISE were not significantly different for $\mathrm{p}<0.05$. 
Table 3

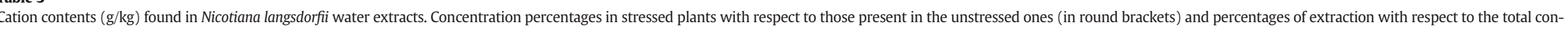
centrations (in square brackets).

\begin{tabular}{|c|c|c|c|c|c|c|c|c|c|c|c|c|c|c|}
\hline Analyte & WT & $\begin{array}{l}\text { WT } \\
\text { CS }\end{array}$ & $\begin{array}{l}\text { WT } \\
\text { DS }\end{array}$ & $\begin{array}{l}\text { WT } \\
\text { HS }\end{array}$ & GR & $\begin{array}{l}\text { GR } \\
\text { CS }\end{array}$ & $\begin{array}{l}\text { GR } \\
\text { DS }\end{array}$ & $\begin{array}{l}\text { GR } \\
\text { HS }\end{array}$ & rolC & $\begin{array}{l}\text { rolC } \\
\text { CS }\end{array}$ & $\begin{array}{l}\text { rolC } \\
\text { DS }\end{array}$ & $\begin{array}{l}\text { rolC } \\
\mathrm{HS}\end{array}$ & Min & Max \\
\hline K & $\begin{array}{l}36.9 \\
{[17 \%]}\end{array}$ & $\begin{array}{l}23.7 \\
(-36 \%) \\
{[15 \%]}\end{array}$ & $\begin{array}{l}32.9 \\
(-11 \%) \\
{[12 \%]}\end{array}$ & $\begin{array}{l}25.4 \\
(-31 \%) \\
{[14 \%]}\end{array}$ & $\begin{array}{l}32.2 \\
{[12 \%]}\end{array}$ & $\begin{array}{l}21.7 \\
(-33 \%) \\
{[12 \%]}\end{array}$ & $\begin{array}{l}29.2 \\
(-9 \%) \\
{[16 \%]}\end{array}$ & $\begin{array}{l}\mathbf{5 . 8 8} \\
(-82 \%) \\
{[19 \%]}\end{array}$ & $\begin{array}{l}22.4 \\
{[18 \%]}\end{array}$ & $\begin{array}{l}17.8 \\
(-21 \%) \\
{[7 \%]}\end{array}$ & $\begin{array}{l}30.9 \\
(+38 \%) \\
{[7 \%]}\end{array}$ & $\begin{array}{l}4.77 \\
(-79 \%) \\
{[8 \%]}\end{array}$ & $\begin{array}{l}4.77 \\
{[7 \%]}\end{array}$ & $\begin{array}{l}36.9 \\
{[19 \%]}\end{array}$ \\
\hline $\mathrm{Na}$ & $\begin{array}{l}0.96 \\
{[98.4 \%]}\end{array}$ & $\begin{array}{l}0.48 \\
(-50 \%) \\
{[68.2 \%]}\end{array}$ & $\begin{array}{l}0.51 \\
(-47 \%) \\
{[82.8 \%]}\end{array}$ & $\begin{array}{l}0.51 \\
(-47 \%) \\
{[49.0 \%]}\end{array}$ & $\begin{array}{l}1.04 \\
{[90.5 \%]}\end{array}$ & $\begin{array}{l}0.68 \\
(-35 \%) \\
{[91.7 \%]}\end{array}$ & $\begin{array}{l}0.58 \\
(-44 \%) \\
{[60.9 \%]}\end{array}$ & $\begin{array}{l}0.30 \\
(-71 \%) \\
{[28.9 \%]}\end{array}$ & $\begin{array}{l}0.32 \\
{[56.3 \%]}\end{array}$ & $\begin{array}{l}0.38 \\
(+19 \%) \\
{[59.8 \%]}\end{array}$ & $\begin{array}{l}\mathbf{0 . 4 8} \\
(+50 \%) \\
{[100 \%]}\end{array}$ & $\begin{array}{l}0.40 \\
(+25 \%) \\
{[35.7 \%]}\end{array}$ & $\begin{array}{l}0.30 \\
{[28.9 \%]}\end{array}$ & $\begin{array}{l}1.04 \\
{[100 \%]}\end{array}$ \\
\hline Cr & - & $\begin{array}{l}0.19 \\
{[34.8 \%]}\end{array}$ & - & - & - & $\begin{array}{l}0.15 \\
{[26.7 \%]}\end{array}$ & - & - & - & $\begin{array}{l}0.11 \\
{[19.5 \%]}\end{array}$ & - & - & $\begin{array}{l}1.15 \\
{[26.7 \%]}\end{array}$ & $\begin{array}{l}1.19 \\
{[34.8 \%]}\end{array}$ \\
\hline $\mathrm{Al}$ & $\begin{array}{l}1 \times 10^{-3} \\
{[19 \%]}\end{array}$ & $\begin{array}{l}1 \times 10^{-4} \\
(-90 \%) \\
{[15 \%]}\end{array}$ & $\begin{array}{l}1 \times 10^{-3} \\
(=) \\
{[13 \%]}\end{array}$ & $\begin{array}{l}3 \times 10^{-3} \\
(+200 \%) \\
{[2 \%]}\end{array}$ & $\begin{array}{l}1 \times 10^{-4} \\
{[3 \%]}\end{array}$ & $\begin{array}{l}1 \times 10^{-3} \\
(+900 \%) \\
{[5 \%]}\end{array}$ & $\begin{array}{l}1 \times 10^{-3} \\
(+900 \%) \\
{[5 \%]}\end{array}$ & $\begin{array}{l}1 \times 10^{-3} \\
(+900 \%) \\
{[19 \%]}\end{array}$ & $\begin{array}{l}1 \times 10^{-3} \\
{[5 \%]}\end{array}$ & $\begin{array}{l}1 \times 10^{-3} \\
== \\
{[38 \%]}\end{array}$ & $\begin{array}{l}1 \times 10^{-3} \\
(=) \\
{[34 \%]}\end{array}$ & $\begin{array}{l}2 \times 10^{-3} \\
(+100 \%) \\
{[1 \%]}\end{array}$ & $\begin{array}{l}4 \times 10^{-4} \\
{[1 \%]}\end{array}$ & $\begin{array}{l}3 \times 10^{-3} \\
{[38 \%]}\end{array}$ \\
\hline $\mathrm{Ca}$ & $\begin{array}{l}1.46 \\
{[21 \%]}\end{array}$ & $\begin{array}{l}1.22 \\
(-16 \%) \\
{[16 \%]}\end{array}$ & $\begin{array}{l}1.56 \\
(+7 \%) \\
{[15 \%]}\end{array}$ & $\begin{array}{l}0.01 \\
(-99 \%) \\
{[21 \%]}\end{array}$ & $\begin{array}{l}0.94 \\
{[12 \%]}\end{array}$ & $\begin{array}{l}0.72 \\
(-23 \%) \\
{[15 \%]}\end{array}$ & $\begin{array}{l}0.63 \\
(-33 \%) \\
{[21 \%]}\end{array}$ & $\begin{array}{l}0.67 \\
(-29 \%) \\
{[11 \%]}\end{array}$ & $\begin{array}{l}0.85 \\
{[17 \%]}\end{array}$ & $\begin{array}{l}0.74 \\
(-13 \%) \\
{[11 \%]}\end{array}$ & $\begin{array}{l}0.94 \\
(+11 \%) \\
{[7 \%]}\end{array}$ & $\begin{array}{l}0.41 \\
(-52 \%) \\
{[8 \%]}\end{array}$ & $\begin{array}{l}0.31 \\
{[7 \%]}\end{array}$ & $\begin{array}{l}1.56 \\
{[21 \%]}\end{array}$ \\
\hline $\mathrm{Fe}$ & $\begin{array}{l}3.9 \times 10^{-2} \\
{[10 \%]}\end{array}$ & $\begin{array}{l}2.1 \times 10^{-2} \\
(-46 \%) \\
{[5 \%]}\end{array}$ & $\begin{array}{l}7 \times 10^{-2} \\
(+79 \%) \\
{[2 \%]}\end{array}$ & $\begin{array}{l}6 \times 10^{-2} \\
(+54 \%) \\
{[7 \%]}\end{array}$ & $\begin{array}{l}1.1 \times 10^{-2} \\
{[4 \%]}\end{array}$ & $\begin{array}{l}1.3 \times 10^{-2} \\
(18 \%) \\
{[6 \%]}\end{array}$ & $\begin{array}{l}4 \times 10^{-2} \\
(+264 \%) \\
{[3 \%]}\end{array}$ & $\begin{array}{l}5 \times 10^{-2} \\
(+355 \%) \\
{[2 \%]}\end{array}$ & $\begin{array}{l}6 \times 10^{-2} \\
{[7 \%]}\end{array}$ & $\begin{array}{l}1.4 \times 10^{-2} \\
(-77 \%) \\
{[4 \%]}\end{array}$ & $\begin{array}{l}1.4 \times 10^{-2} \\
(-77 \%) \\
{[3 \%]}\end{array}$ & $\begin{array}{l}7 \times 10^{-2} \\
(+17 \%) \\
{[4 \%]}\end{array}$ & $\begin{array}{l}4 \times 10^{-3} \\
{[2 \%]}\end{array}$ & $\begin{array}{l}0.04 \\
{[10 \%]}\end{array}$ \\
\hline $\mathrm{Mg}$ & $\begin{array}{l}0.96 \\
{[51.2 \%]}\end{array}$ & $\begin{array}{l}0.82 \\
(-15 \%) \\
{[48.4 \%]}\end{array}$ & $\begin{array}{l}1.13 \\
(+18 \%) \\
{[58.1 \%]}\end{array}$ & $\begin{array}{l}6.10 \\
(+535 \%) \\
{[26.6 \%]}\end{array}$ & $\begin{array}{l}0.76 \\
{[59.0 \%]}\end{array}$ & $\begin{array}{l}0.50 \\
(-34 \%) \\
{[28.1 \%]}\end{array}$ & $\begin{array}{l}0.70 \\
(-8 \%) \\
{[63.7 \%]}\end{array}$ & $\begin{array}{l}0.66 \\
(-13 \%) \\
{[23.6 \%]}\end{array}$ & $\begin{array}{l}0.81 \\
{[45.9 \%]}\end{array}$ & $\begin{array}{l}0.52 \\
(-36 \%) \\
{[36.7 \%]}\end{array}$ & $\begin{array}{l}1.00 \\
(+23 \%) \\
{[61.1 \%]}\end{array}$ & $\begin{array}{l}0.51 \\
(-37 \%) \\
{[25.2 \%]}\end{array}$ & $\begin{array}{l}0.44 \\
{[23.6 \%]}\end{array}$ & $\begin{array}{l}1.13 \\
{[63.7 \%]}\end{array}$ \\
\hline Mn & $\begin{array}{l}0.18 \\
{[49.1 \%]}\end{array}$ & $\begin{array}{l}0.10 \\
(-44 \%) \\
{[42.8 \%]}\end{array}$ & $\begin{array}{l}0.17 \\
(-6 \%) \\
{[47.2 \%]}\end{array}$ & $\begin{array}{l}0.23 \\
(+28 \%) \\
{[26.1 \%]}\end{array}$ & $\begin{array}{l}0.13 \\
{[41.2 \%]}\end{array}$ & $\begin{array}{l}0.07 \\
(-46 \%) \\
{[29.8 \%]}\end{array}$ & $\begin{array}{l}0.09 \\
(-31 \%) \\
{[41.5 \%]}\end{array}$ & $\begin{array}{l}0.13 \\
(=) \\
{[15.6 \%]}\end{array}$ & $\begin{array}{l}0.11 \\
{[100 \%]}\end{array}$ & $\begin{array}{l}0.07 \\
(-36 \%) \\
{[30.5 \%]}\end{array}$ & $\begin{array}{l}0.13 \\
(+18 \%) \\
{[40.5 \%]}\end{array}$ & $\begin{array}{l}0.03 \\
(-73 \%) \\
{[17.8 \%]}\end{array}$ & $\begin{array}{l}0.03 \\
{[15.6 \%]}\end{array}$ & $\begin{array}{l}0.18 \\
{[100 \%]}\end{array}$ \\
\hline P & $\begin{array}{l}8.64 \\
{[68.6 \%]}\end{array}$ & $\begin{array}{l}6.53 \\
(-24 \%) \\
{[58.9 \%]}\end{array}$ & $\begin{array}{l}9.89 \\
(+14 \%) \\
{[77.0 \%]}\end{array}$ & $\begin{array}{l}1.84 \\
(-79 \%) \\
{[27.1 \%]}\end{array}$ & $\begin{array}{l}8.35 \\
{[76.4 \%]}\end{array}$ & $\begin{array}{l}5.71 \\
(-32 \%) \\
{[49.3 \%]}\end{array}$ & $\begin{array}{l}12.7 \\
(+52 \%) \\
{[100 \%]}\end{array}$ & $\begin{array}{l}1.55 \\
(-81 \%) \\
{[27.1 \%]}\end{array}$ & $\begin{array}{l}8.59 \\
{[100 \%]}\end{array}$ & $\begin{array}{l}7.32 \\
(-15 \%) \\
{[53.8 \%]}\end{array}$ & $\begin{array}{l}11.6 \\
(+35 \%) \\
{[77.8 \%]}\end{array}$ & $\begin{array}{l}1.36 \\
(-84 \%) \\
{[29.2 \%]}\end{array}$ & $\begin{array}{l}1.36 \\
{[27.1 \%]}\end{array}$ & $\begin{array}{l}12.7 \\
{[100 \%]}\end{array}$ \\
\hline $\mathrm{Si}$ & $\begin{array}{l}3.0 \times 10^{-2} \\
{[34.2 \%]}\end{array}$ & $\begin{array}{l}3.8 \times 10^{-2} \\
(+27 \%) \\
{[12.2 \%]}\end{array}$ & $\begin{array}{l}1.6 \times 10^{-2} \\
(-47 \%) \\
{[34.1 \%]}\end{array}$ & $\begin{array}{l}1.7 \times 10^{-2} \\
(-43 \%) \\
{[5.00 \%]}\end{array}$ & $\begin{array}{l}2.4 \times 10^{-2} \\
{[38.5 \%]}\end{array}$ & $\begin{array}{l}2.6 \times 10^{-2} \\
(+8 \%) \\
{[7.84 \%]}\end{array}$ & $\begin{array}{l}1.5 \times 10^{-2} \\
(-38 \%) \\
{[20.8 \%]}\end{array}$ & $\begin{array}{l}0.6 \times 10^{-2} \\
(-75 \%) \\
{[5.26 \%]}\end{array}$ & $\begin{array}{l}1.5 \times 10^{-2} \\
{[29.3 \%]}\end{array}$ & $\begin{array}{l}1.5 \times 10^{-2} \\
(=) \\
{[8.31 \%]}\end{array}$ & $\begin{array}{l}2.2 \times 10^{-2} \\
(+47 \%) \\
{[34.0 \%]}\end{array}$ & $\begin{array}{l}0.6 \times 10^{-2} \\
(-60 \%) \\
{[5.44 \%]}\end{array}$ & $\begin{array}{l}6 \times 10^{-3} \\
{[5.00 \%]}\end{array}$ & $\begin{array}{l}0.04 \\
{[38.4 \%]}\end{array}$ \\
\hline $\mathrm{Zn}$ & $\begin{array}{l}0.08 \\
{[50.7 \%]}\end{array}$ & $\begin{array}{l}0.05 \\
(-38 \%) \\
{[52.8 \%]}\end{array}$ & $\begin{array}{l}0.05 \\
(-38 \%) \\
{[36.4 \%]}\end{array}$ & $\begin{array}{l}0.06 \\
(-25 \%) \\
{[31.6 \%]}\end{array}$ & $\begin{array}{l}0.05 \\
{[40.4 \%]}\end{array}$ & $\begin{array}{l}0.03 \\
(-40 \%) \\
{[30.6 \%]}\end{array}$ & $\begin{array}{l}0.05 \\
(=) \\
{[66.5 \%]}\end{array}$ & $\begin{array}{l}0.06 \\
(+20 \%) \\
{[20.5 \%]}\end{array}$ & $\begin{array}{l}0.06 \\
{[19.8 \%]}\end{array}$ & $\begin{array}{l}0.02 \\
(-67) \\
{[33.1 \%]}\end{array}$ & $\begin{array}{l}0.06 \\
(=) \\
{[47.2 \%]}\end{array}$ & $\begin{array}{l}0.02 \\
(-67 \%) \\
{[30.5 \%]}\end{array}$ & $\begin{array}{l}0.02 \\
{[19.8 \%]}\end{array}$ & $\begin{array}{l}0.08 \\
{[66.5 \%]}\end{array}$ \\
\hline Total & 49.2 & 33.0 & 46.3 & 9.17 & 43.5 & 29.5 & 44.0 & 7.68 & 33.1 & 26.8 & 45.2 & 7.58 & & \\
\hline
\end{tabular}


Table 4

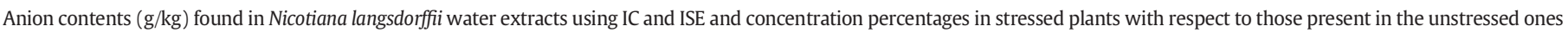
(in brackets).

\begin{tabular}{|c|c|c|c|c|c|c|c|c|c|c|c|c|}
\hline Analyte & WT & $\begin{array}{l}\text { WT } \\
\text { CS }\end{array}$ & $\begin{array}{l}\text { WT } \\
\text { DS }\end{array}$ & $\begin{array}{l}\text { WT } \\
\text { HS }\end{array}$ & GR & $\begin{array}{l}\text { GR } \\
\text { CS }\end{array}$ & $\begin{array}{l}\text { GR } \\
\text { DS }\end{array}$ & $\begin{array}{l}\text { GR } \\
\text { HS }\end{array}$ & rolc & $\begin{array}{l}\text { rolC } \\
\text { CS }\end{array}$ & $\begin{array}{l}\text { rolC } \\
\text { DS }\end{array}$ & $\begin{array}{l}\text { rolC } \\
\text { HS }\end{array}$ \\
\hline \multicolumn{13}{|l|}{ IC } \\
\hline $\mathrm{Cl}^{-}$ & 16.3 & $\begin{array}{l}8.51 \\
(-48 \%)\end{array}$ & $\begin{array}{l}2.40 \\
(-85 \%)\end{array}$ & $\begin{array}{l}3.35 \\
(-67 \%)\end{array}$ & 14.6 & $\begin{array}{l}10.8 \\
(-23 \%)\end{array}$ & $\begin{array}{l}12.0 \\
(-26 \%)\end{array}$ & $\begin{array}{l}6.11 \\
(-56 \%)\end{array}$ & 15.8 & $\begin{array}{l}8.73 \\
(-44 \%)\end{array}$ & $\begin{array}{l}10.1 \\
(-36 \%)\end{array}$ & $\begin{array}{l}7.2 \\
(-54 \%)\end{array}$ \\
\hline $\mathrm{NO}_{3}^{-}$ & 63.8 & $\begin{array}{l}36.0 \\
(-44 \%)\end{array}$ & $\begin{array}{l}11.6 \\
(-81 \%)\end{array}$ & $\begin{array}{l}55.2 \\
(-13 \%)\end{array}$ & 54.0 & $\begin{array}{l}30.9 \\
(-43 \%)\end{array}$ & $\begin{array}{l}45.3 \\
(-29 \%)\end{array}$ & $\begin{array}{l}43.0 \\
(-20 \%)\end{array}$ & 55.8 & $\begin{array}{l}30.3 \\
(-46 \%)\end{array}$ & $\begin{array}{l}36.2 \\
(-35 \%)\end{array}$ & $\begin{array}{l}55.3 \\
(-1 \%)\end{array}$ \\
\hline \multicolumn{13}{|l|}{ ISE } \\
\hline $\mathrm{Cl}^{-}$ & 15.6 & $\begin{array}{l}15.2 \\
(-3 \%)\end{array}$ & $\begin{array}{l}12.2 \\
(-22 \%)\end{array}$ & $\begin{array}{l}13.3 \\
(-13 \%)\end{array}$ & 16.4 & $\begin{array}{l}13.1 \\
(-20 \%)\end{array}$ & $\begin{array}{l}16.6 \\
(+6)\end{array}$ & $\begin{array}{l}12.8 \\
(-22 \%)\end{array}$ & 17.7 & $\begin{array}{l}17.6 \\
(-1 \%)\end{array}$ & $\begin{array}{l}17.7 \\
(0 \%)\end{array}$ & $\begin{array}{l}16.8 \\
(-5 \%)\end{array}$ \\
\hline $\mathrm{NO}_{3}^{-}$ & 77.4 & $\begin{array}{l}45.0 \\
(-42 \%)\end{array}$ & $\begin{array}{l}12.5 \\
(-83 \%)\end{array}$ & $\begin{array}{l}68.6 \\
(-13 \%)\end{array}$ & 39.0 & $\begin{array}{l}12.6 \\
(-68 \%)\end{array}$ & $\begin{array}{l}37.9 \\
(-51 \%)\end{array}$ & $\begin{array}{l}35.7 \\
(-8 \%)\end{array}$ & 39.3 & $\begin{array}{l}9.09 \\
(-77 \%)\end{array}$ & $\begin{array}{l}29.4 \\
(-25 \%)\end{array}$ & $\begin{array}{l}40.8 \\
(+4)\end{array}$ \\
\hline
\end{tabular}

As to $\mathrm{NO}_{3}^{-}$, the concentration observed with ISE is overestimated for the WT plants in comparison with IC, while for the genetically modified plants the concentration determined by ISE was always lower. For this anion the concentrations obtained were not significantly different for $\mathrm{p}<0.05$ for all the samples, with the exception of GR-CS and rolC-CS.

a

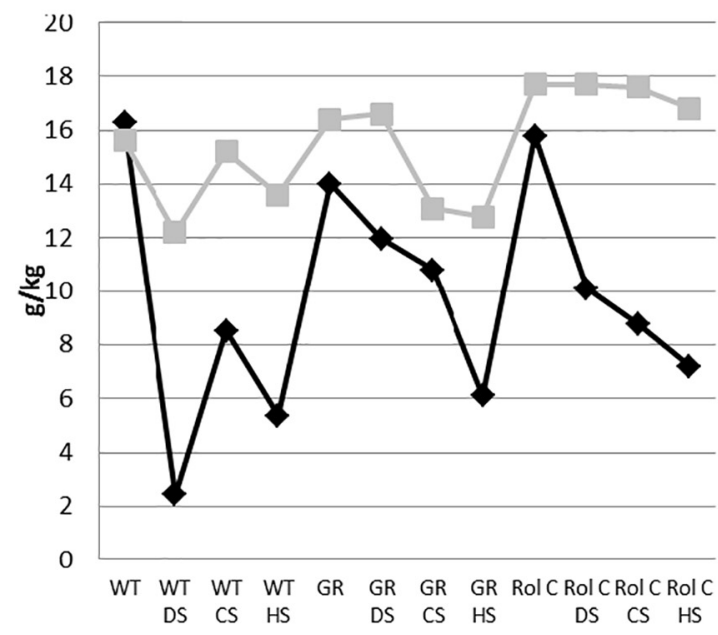

b

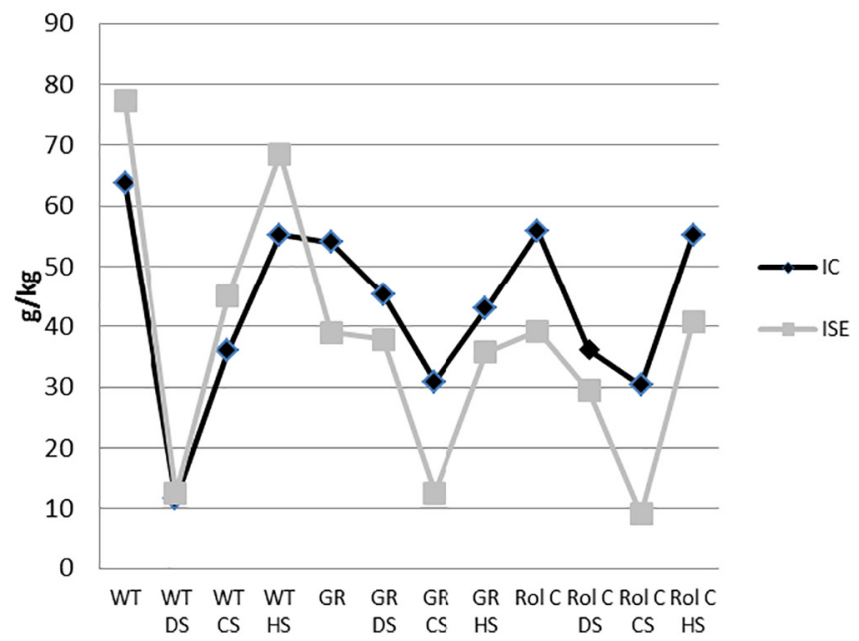

Fig. 1. Concentrations of a) $\mathrm{Cl}^{-}$and b) $\mathrm{NO}_{3}^{-}$measured using ion chromatography and potentiometry.
We can make some considerations on the matrix effect observed using the two techniques. Table 5 reports the equations of the calibration curves obtained for each determination in HPW and in sample matrices using the two techniques.

The adopted conditions permitted us to obtain well defined chromatograms, with the peaks of interest at $t=6.35 \mathrm{~min}$ and $t=$ $11.05 \mathrm{~min}$ for $\mathrm{Cl}^{-}$and $\mathrm{NO}_{3}^{-}$respectively. The repeatability obtained in three replicates of the sample extracts was good: the relative standard deviation was always lower than $2.5 \%$. To better value the effect of the sample matrix we sequentially added aliquots (three aliquots of $0.5 \mathrm{ml}$ ) of each plant extract to $100 \mathrm{ml}$ HPW standard solutions (containing $4 \mathrm{mg} / \mathrm{l}$ of $\mathrm{Cl}^{-}$and $1 \mathrm{mg} / \mathrm{l}$ of $\mathrm{NO}_{3}^{-}$): a linear response was obtained. We can observe similar slope values for all the considered sample solutions both determining $\mathrm{Cl}^{-}$and $\mathrm{NO}_{3}^{-}$. The slopes of the calibration equation obtained analysing standard solutions prepared in water were higher than that obtained in the sample matrix in the case of $\mathrm{Cl}^{-}$and lower in the case of $\mathrm{NO}_{3}^{-}$.

Potentiometry is a cheaper and simpler method than IC, but the potentiometric response can be subject to interferences from other species possibly present in solution [40-41], which can bind to the ISE membrane, leading to an overestimation of the analyte concentration, or bind to the analyte in solution, hindering its interaction with the membrane and thus causing a negative interference.

The theoretical slope of ISEs is $|59,16|$ working at room temperature, but the range $|54|-|60|$ is considered satisfactory (user guide, Thermo scientific). As we can see from the table, performing the calibration with standard solutions prepared in HPW, the ISEs response is as expected. On the contrary the presence of the sample matrix drastically reduced the slope values: in the case of $\mathrm{Cl}^{-}$it was -36.54 for all the types of plants, while in the case of $\mathrm{NO}_{3}^{-}$it ranged from -32 to -23 decreasing (in absolute value) in the order WT $>\mathrm{GR}>$ rolC. This can be caused by the fact that the extracts contained high concentration of other ions in addition to the analytes: salts present in sample solutions may be extracted into the electrode membrane, causing deviation from the theoretical response. The slope variation follows the same order as the total ion content present in the water extract (WT $>\mathrm{GR}>$ rolC).

We valued the effect of the presence of other anions in the extracts, by analysing synthetic solutions containing $4 \mathrm{mg} / \mathrm{l} \mathrm{of} \mathrm{Cl}^{-}$and $\mathrm{NO}_{3}^{-}$in the presence of $10 \mathrm{mg} / \mathrm{l}$ of potential interfering agents $\left(\mathrm{Br}^{-}, \mathrm{I}^{-}\right.$, $\mathrm{CH}_{3} \mathrm{COO}, \mathrm{NO}_{3}^{-}$or $\mathrm{Cl}^{-}$). The results are reported in Table 6 .

The presence of $\mathrm{Br}^{-}$seems to have an acceptable effect on the determination of the considered analytes; also the presence of $\mathrm{Cl}^{-}$or $\mathrm{NO}_{3}^{-}$ does not cause a variation in the measurement of the other marker. The presence of acetate ions has opposite effects on the determination of $\mathrm{Cl}^{-}$and $\mathrm{NO}_{3}^{-}$, and causes a strong positive interference on the determination of the latter. $\mathrm{I}^{-}$gives rise to an overestimation of the $\mathrm{Cl}^{-}$content and does not permit the quantification of $\mathrm{NO}_{3}^{-}$, because its presence does not permit to reveal any variation in the instrumental potentiometric response after the additions of standard solutions. 
Table 5

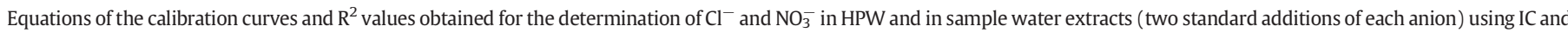
potentiometry with ISE.

\begin{tabular}{|c|c|c|c|c|c|}
\hline \multirow[b]{2}{*}{ Technique } & \multirow[b]{2}{*}{ Matrix } & \multicolumn{2}{|l|}{$\mathrm{Cl}^{-}$} & \multicolumn{2}{|l|}{$\mathrm{NO}_{3}^{-}$} \\
\hline & & Equation & $\mathrm{R}^{2}$ & Equation & $\mathrm{R}^{2}$ \\
\hline IC & HPW & $y=221.824 x+21.778$ & 0.9999 & $\mathrm{y}=116.543 \mathrm{x}+13.071$ & $>0.9999$ \\
\hline IC & WT extract & $y=160.210 x+136.387$ & 0.9968 & $y=148.971 x+355.313$ & $>0.9999$ \\
\hline IC & GR extract & $y=150.022 x+162.058$ & 0.9984 & $y=145.094 x+657.251$ & 0.9993 \\
\hline IC & rolC extract & $y=153.036 x+154.193$ & 0.9998 & $y=141.568 x+429.300$ & 0.9937 \\
\hline ISE & HPW extract & $y=-56.584 x+189.1$ & 0.9967 & $y=-60.33 x+93.68$ & 0.9837 \\
\hline ISE & WT extract & $y=-36.54 x+148.5$ & $>0.9999$ & $y=-31.71 x+52.5$ & $>0.9999$ \\
\hline ISE & GR extract & $y=-36.54 x+147.5$ & $>0.9999$ & $y=-28.08 x+58.5$ & 0.985 \\
\hline ISE & rolC extract & $y=-36.54 x+146.5$ & $>0.9999$ & $y=-23.25 x+31.0$ & $>0.9999$ \\
\hline
\end{tabular}

In any case, even if repeatability with ISEs is limited by factors such as temperature fluctuations and noise, electrode measurements repeatable to $\pm 1,5 \%$ were obtained, which is satisfactory.

\subsection{Chemometric treatment}

The chemometric treatment of the experimental data was carried out through the application of a well-known statistical multivariate analysis technique: Principal Component Analysis (PCA).

The chemometric study was carried out $\mathrm{i}$ ) on the total cation content in the digested solution (Fig. 2a); ii) on the cation content in the water extracts (Fig. 2b); iii) on the whole data set (all the cations and anions) found for the water extract solutions (Fig. 2c); iv) considering only the concentrations of the markers in the water extract solutions (Fig. 2d). We considered the concentration values and not the percentages of extraction, since it was not possible to determine the total content of the anions: in this manner we can compare the results obtained considering only the markers, only the cations and the whole data set. We took into account the first two PCs. Pearson's correlation coefficients for all data treatments are reported in Tables A1-A4 (Appendix A).

As we can observe in the combined plot of scores and loadings in Fig. 2a resulting from the treatment of data about the total cation content, the samples are grouped in different areas of the graph on the basis of the induced stress. The scores of unstressed and DS-plants are in the same area of the biplot because these are generally characterized by the highest amount of $\mathrm{K}, \mathrm{Mn}$ and $\mathrm{Zn}$; the only exception is represented by GR-DS that contains a higher level of Na. HS-plants are grouped together in the opposite plot region in comparison with the direction of the loadings, since they generally contain the lowest concentrations of cations. Also the chemically stressed plant are grouped together and seem to be characterized by higher concentration of $\mathrm{Al}, \mathrm{Mg}$ and $\mathrm{Si}$. The genetic modifications appear to have no effect on the classification of the samples on the basis of the cation content.

Regarding the loadings, $\mathrm{K}$ is correlated with $\mathrm{P}\left(\mathrm{r}^{2}=0,820\right)$, $\mathrm{Mn}\left(\mathrm{r}^{2}=\right.$ $0,754), \mathrm{Fe}\left(\mathrm{r}^{2}=0,721\right), \mathrm{Ca}\left(\mathrm{r}^{2}=0,717\right)$ and $\mathrm{Zn}\left(\mathrm{r}^{2}=0,716\right)$ and all these elements heavily load on $\mathrm{F} 2$; Na shows a particular behavior in comparison to most of the measured cations. Good correlation is observed among $\mathrm{Al}, \mathrm{Mg}$ and $\mathrm{Si}$; they all load on $\mathrm{F} 1$, that seems to characterize CS-plants.

Considering the cation content in the water extracts (Fig. 2b), the scores show the same behavior as previously described for the total concentrations, with the only exception of GR-DS that is grouped together

Table 6

Contents $(\mathrm{g} / \mathrm{kg})$ of $\mathrm{Cl}^{-}$and $\mathrm{NO}_{3}^{-}$measured in water by ISE in the presence of potential interfering agents. Expected concentration: $4,00 \mathrm{~g} / \mathrm{kg}$.

\begin{tabular}{lllllll}
\hline Analyte & $\mathrm{HPW}$ & $\mathrm{Br}^{-}$ & $\mathrm{I}^{-}$ & $\mathrm{CH}_{3} \mathrm{COO}^{-}$ & $\mathrm{NO}_{3}^{-}$ & $\mathrm{Cl}^{-}$ \\
\hline $\mathrm{Cl}^{-}$ & 4.00 & 4.09 & $\mathbf{6 . 0 8}$ & 3.90 & 3.97 & - \\
$\mathrm{NO}_{3}^{-}$ & 4.05 & 4.07 & - & $\mathbf{6 . 4 0}$ & - & 4.08
\end{tabular}

with the other DS-plants. As observed for the total content, K shows correlation with $\mathrm{Mn}\left(\mathrm{r}^{2}=0.904\right), \mathrm{P}\left(\mathrm{r}^{2}=0.885\right), \mathrm{Zn}\left(\mathrm{r}^{2}=0.868\right), \mathrm{Ca}\left(\mathrm{r}^{2}=\right.$ $0.781)$ and $\operatorname{Mg}\left(r^{2}=0,766\right)$. No correlation is observed between $\mathrm{Na}$ and the other elements (the maximum value of correlation coefficient of $\mathrm{Na}$ is with $\mathrm{K}, \mathrm{r}^{2}=0.621$ ).

Introducing the results obtained for the anions in the treatment (Fig. 2c), the resulting biplot confirms that the element content in the plants is especially influenced by the induced stress and not by the type of plant (wild or modified). In this case, the scores of the unstressed plants are in the first quarter of the biplot, well separated from all the stressed ones, the thermally-stressed plants are in the opposite region in comparison with most of the loadings, since they are generally characterized by lower concentrations that the other ones; the plants affected by hydric and chemical stress form a group in the opposite region in comparison to the direction of the loadings of $\mathrm{Cl}^{-}$and $\mathrm{NO}_{3}^{-}$. While the cations mainly load on F1, the anions load on F2 (even if they are only partially correlated, $\left.r^{2}=0,601\right)$. Na shows a similar behavior to the other cations, but it is weakly correlated with the other analytes; in particular it shows the highest correlation coefficient with the other cationic marker, $\mathrm{K}\left(\mathrm{r}^{2}=\right.$ $0,621)$. Remarkable correlations $\left(r^{2}>0,750\right)$ are observed between $\mathrm{K}$ and $\mathrm{Ca}, \mathrm{Mg}, \mathrm{P}, \mathrm{Mn}$ and $\mathrm{Zn}$. The two anions are not strongly correlated with any cation.

Considering only $\mathrm{K}, \mathrm{Na}, \mathrm{Cl}^{-}$and $\mathrm{NO}_{3}^{-}$concentrations in the water extract (Fig. 2d), we can see that all the loadings are oriented in the same direction along F1, with cations and anions having opposite loadings on F2. Their direction is toward the unstressed plants (in particular the anions), in opposite direction in comparison to thermally stressed plants; chemically and water-stressed plants are grouped together as just previously explained. The chemometric treatment of the whole data set and of the marker data alone is able to distinguish the same groups of samples, demonstrating how these analytes represent good markers to monitor the effect of stresses in plants. In particular, the plants are grouped on the basis of the stress treatment and not for the genetic modification.

\section{Conclusions}

The presence of genetic modification in Nicotiana langsdorffii causes a change of its capacity of absorption and of the facility of release of the considered elements; moreover genetic modifications cause a different plant response to stresses. In particular, the modification with rolC increases the capacity of the plant to adsorb a pollutant, $\mathrm{Cr}$, and decreases its release in water. This behavior can be useful to develop modified plants able to be adopted for phytoremediation purposes. The presence of GR influences the inorganic composition of the plant, confirming its effect on the whole plant system, well known from a hormonal point of view.

Stress conditions have strong effects on the content of inorganic species, causing a reduction of their total concentrations, and of the extractable amount of cations and anions: the effect depends on the type of stress, and the considered analyte. For example, after applying a heat thermal stress, we observed a drastic reduction of cation content, while 


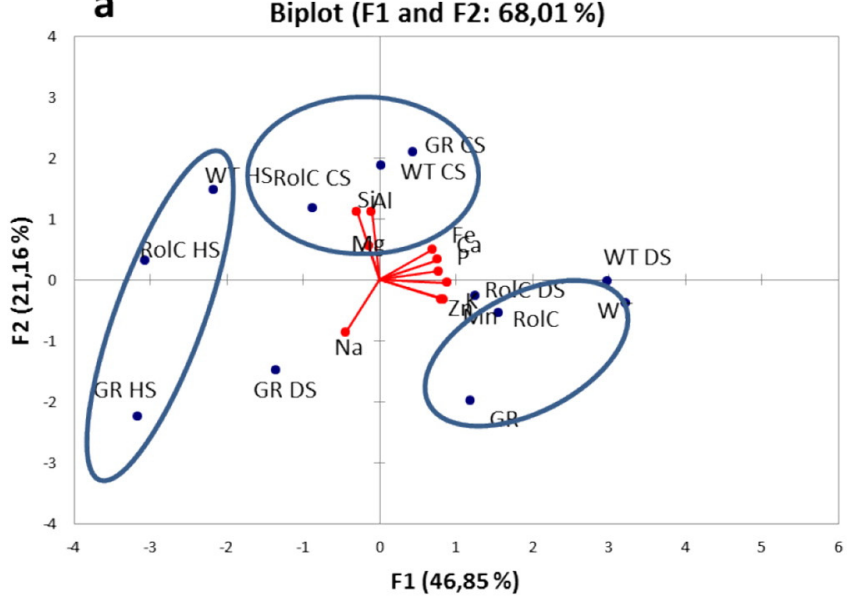

C

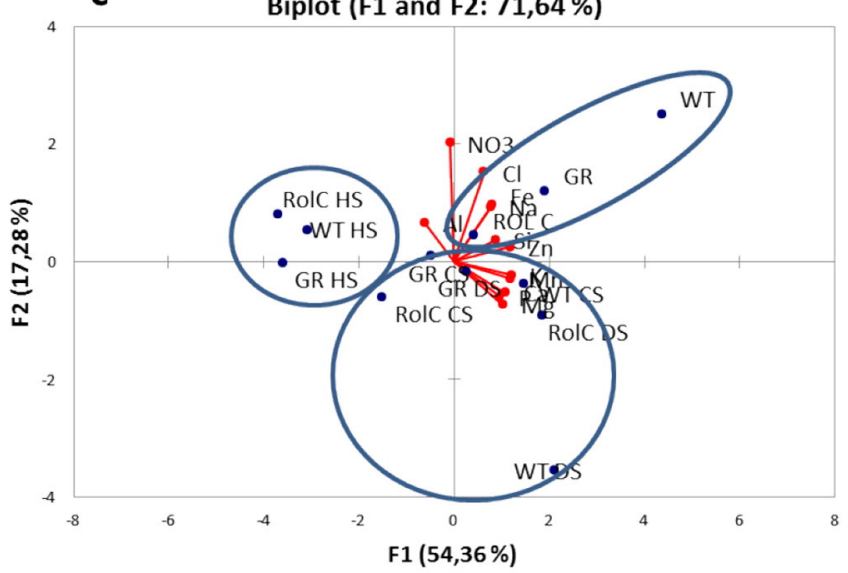

b

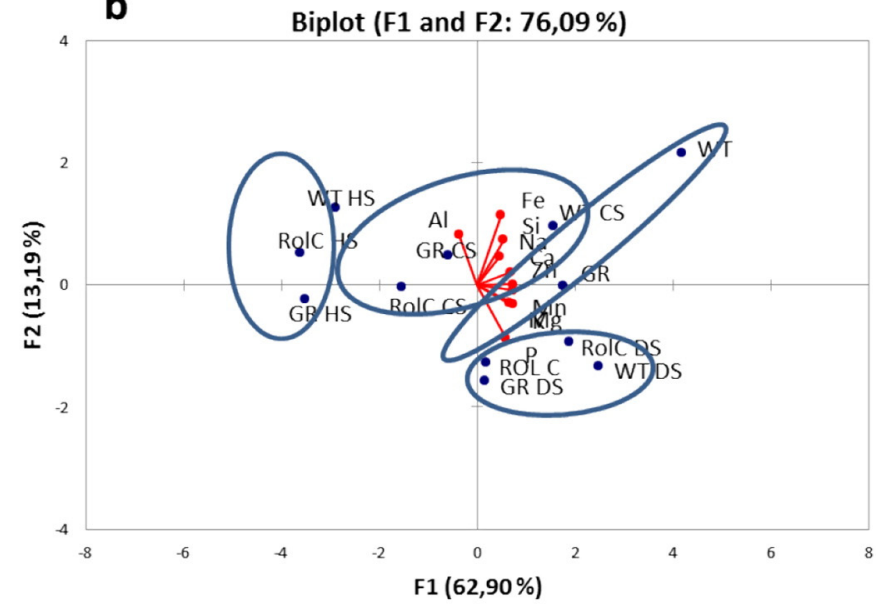

d

Biplot (F1 and F2: $86,80 \%$ )

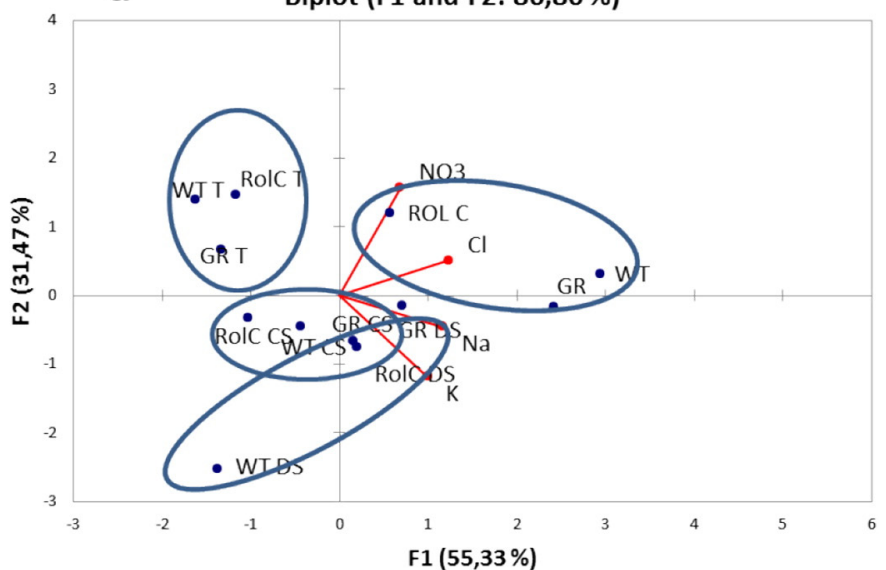

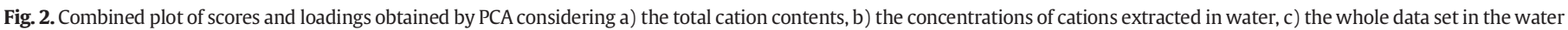
extract, d) the concentrations of the markers $\left(\mathrm{Cl}^{-}, \mathrm{NO}_{3}^{-}, \mathrm{K}\right.$ and $\left.\mathrm{Na}\right)$ in the water extract solutions.

water deficit and the addition of $\mathrm{Cr}$ gave rise to a less extensive decrease. A different effect was observed for the anions, which showed the greatest reduction in the case of water deficit.

Chemometrics helped us to value the whole dataset: differences among the considered plants derive in particular from the presence and type of stress. The selected markers seem to be a good choice, since their loadings are able to give the same information as that obtained considering the whole dataset.

The use of potentiometry for the determination of anions in plant extracts offers some advantages, such as low costs and portability, over other techniques, but it is undoubtedly influenced by the presence of other species in solution. It might be used as for a first screening or to compare the effects of different parameters in a relative mode without absolute values.
The study of the behavior of plants and the effect of genetic modifications in different environmental conditions can be very useful i) to predict the variations induced in the normal development of plants caused by environmental pollution and climatic variations, also taking into account the global warming that is affecting our Planet; and ii) to develop new plant species with higher resistance to particular conditions. The procedure adopted for this study can be followed in other investigations with different plants and different causes of stress.

\section{Funding}

This study was partially funded by the Italian Ministry of University and Research (MIUR) within the framework of the PRIN-2007 (2007TMHTNW_004) and PRIN-2009 (20098TN4CY_004) projects.

\section{Appendix A}

Table A1

Pearson's correlation matrix for the total cation content.

\begin{tabular}{|c|c|c|c|c|c|c|c|c|c|c|}
\hline Variable & $\mathrm{Mg}$ & $\mathrm{Na}$ & $\mathrm{Ca}$ & $\mathrm{P}$ & $\mathrm{Fe}$ & $\mathrm{Al}$ & $\mathrm{Mn}$ & $\mathrm{Zn}$ & $\mathrm{Si}$ & K \\
\hline $\mathrm{Mg}$ & 1 & -0.069 & 0.178 & -0.390 & -0.006 & 0.138 & 0.033 & 0.112 & 0.398 & -0.427 \\
\hline $\mathrm{Na}$ & -0.069 & 1 & -0.479 & -0.630 & -0.318 & -0.383 & -0.258 & -0.129 & -0.217 & -0.424 \\
\hline $\mathrm{Ca}$ & 0.178 & -0.479 & 1 & 0.436 & 0.614 & -0.019 & 0.781 & 0.701 & 0.017 & 0.717 \\
\hline $\mathrm{P}$ & -0.390 & -0.630 & 0.436 & 1 & 0.615 & 0.064 & 0.576 & 0.546 & -0.263 & 0.820 \\
\hline $\mathrm{Fe}$ & -0.006 & -0.318 & 0.614 & 0.615 & 1 & 0.242 & 0.516 & 0.595 & 0.108 & 0.721 \\
\hline
\end{tabular}


Table A1 (continued)

\begin{tabular}{|c|c|c|c|c|c|c|c|c|c|c|}
\hline Variable & Mg & $\mathrm{Na}$ & $\mathrm{Ca}$ & $\mathrm{P}$ & $\mathrm{Fe}$ & $\mathrm{Al}$ & Mn & $\mathrm{Zn}$ & $\mathrm{Si}$ & K \\
\hline $\mathrm{Al}$ & 0.138 & -0.383 & -0.019 & 0.064 & 0.242 & 1 & -0.290 & -0.310 & 0.452 & -0.128 \\
\hline Mn & 0.033 & -0.258 & 0.781 & 0.576 & 0.516 & -0.290 & 1 & 0.947 & -0.488 & 0.754 \\
\hline $\mathrm{Zn}$ & 0.112 & -0.129 & 0.701 & 0.546 & 0.595 & -0.310 & 0.947 & 1 & -0.413 & 0.716 \\
\hline $\mathrm{Si}$ & 0.398 & -0.217 & 0.017 & -0.263 & 0.108 & 0.452 & -0.488 & -0.413 & 1 & -0.257 \\
\hline K & -0.427 & -0.424 & 0.717 & 0.820 & 0.721 & -0.128 & 0.754 & 0.716 & -0.257 & 1 \\
\hline
\end{tabular}

Table A2

Pearson's correlation matrix for the cation concentrations in the water extract.

\begin{tabular}{|c|c|c|c|c|c|c|c|c|c|c|}
\hline Variable & $\mathrm{Mg}$ & $\mathrm{Na}$ & $\mathrm{Ca}$ & $\mathrm{P}$ & $\mathrm{Fe}$ & $\mathrm{Al}$ & Mn & $\mathrm{Zn}$ & $\mathrm{Si}$ & K \\
\hline $\mathrm{Mg}$ & 1 & 0.223 & 0.870 & 0.663 & 0.349 & -0.242 & 0.916 & 0.852 & 0.432 & 0.766 \\
\hline $\mathrm{Na}$ & 0.223 & 1 & 0.364 & 0.313 & 0.538 & -0.362 & 0.524 & 0.504 & 0.459 & 0.621 \\
\hline $\mathrm{Ca}$ & 0.870 & 0.364 & 1 & 0.536 & 0.606 & -0.263 & 0.918 & 0.805 & 0.650 & 0.781 \\
\hline $\mathrm{P}$ & 0.663 & 0.313 & 0.536 & 1 & 0.190 & -0.580 & 0.704 & 0.702 & 0.345 & 0.885 \\
\hline $\mathrm{Fe}$ & 0.349 & 0.538 & 0.606 & 0.190 & 1 & -0.069 & 0.526 & 0.603 & 0.696 & 0.494 \\
\hline $\mathrm{Al}$ & -0.242 & -0.362 & -0.263 & -0.580 & -0.069 & 1 & -0.346 & -0.374 & -0.302 & -0.567 \\
\hline Mn & 0.916 & 0.524 & 0.918 & 0.704 & 0.526 & -0.346 & 1 & 0.916 & 0.522 & 0.904 \\
\hline $\mathrm{Zn}$ & 0.852 & 0.504 & 0.805 & 0.702 & 0.603 & -0.374 & 0.916 & 1 & 0.606 & 0.868 \\
\hline $\mathrm{Si}$ & 0.432 & 0.459 & 0.650 & 0.345 & 0.696 & -0.302 & 0.522 & 0.606 & 1 & 0.597 \\
\hline K & 0.766 & 0.621 & 0.781 & 0.885 & 0.494 & -0.567 & 0.904 & 0.868 & 0.597 & 1 \\
\hline
\end{tabular}

Table A3

Pearson's correlation matrix for the whole data set of element concentration in water extract.

\begin{tabular}{|c|c|c|c|c|c|c|c|c|c|c|c|c|}
\hline Variable & $\mathrm{Mg}$ & $\mathrm{Na}$ & $\mathrm{Ca}$ & $\mathrm{P}$ & $\mathrm{Fe}$ & $\mathrm{Al}$ & Mn & $\mathrm{Zn}$ & $\mathrm{Si}$ & $\mathrm{K}$ & $\mathrm{Cl}$ & $\mathrm{NO}_{3}$ \\
\hline $\mathrm{Mg}$ & 1 & 0.223 & 0.870 & 0.663 & 0.349 & -0.242 & 0.916 & 0.852 & 0.432 & 0.766 & 0.096 & -0.198 \\
\hline $\mathrm{Na}$ & 0.223 & 1 & 0.364 & 0.313 & 0.538 & -0.362 & 0.524 & 0.504 & 0.459 & 0.621 & 0.517 & 0.225 \\
\hline $\mathrm{Ca}$ & 0.870 & 0.364 & 1 & 0.536 & 0.606 & -0.263 & 0.918 & 0.805 & 0.650 & 0.781 & 0.115 & -0.272 \\
\hline $\mathrm{P}$ & 0.663 & 0.313 & 0.536 & 1 & 0.190 & -0.580 & 0.704 & 0.702 & 0.345 & 0.885 & 0.425 & -0.256 \\
\hline $\mathrm{Fe}$ & 0.349 & 0.538 & 0.606 & 0.190 & 1 & -0.069 & 0.526 & 0.603 & 0.696 & 0.494 & 0.450 & 0.224 \\
\hline $\mathrm{Al}$ & -0.242 & -0.362 & -0.263 & -0.580 & -0.069 & 1 & -0.346 & -0.374 & -0.302 & -0.567 & -0.288 & 0.433 \\
\hline $\mathrm{Mn}$ & 0.916 & 0.524 & 0.918 & 0.704 & 0.526 & -0.346 & 1 & 0.916 & 0.522 & 0.904 & 0.327 & -0.115 \\
\hline $\mathrm{Zn}$ & 0.852 & 0.504 & 0.805 & 0.702 & 0.603 & -0.374 & 0.916 & 1 & 0.606 & 0.868 & 0.565 & 0.142 \\
\hline $\mathrm{Si}$ & 0.432 & 0.459 & 0.650 & 0.345 & 0.696 & -0.302 & 0.522 & 0.606 & 1 & 0.597 & 0.364 & -0.029 \\
\hline K & 0.766 & 0.621 & 0.781 & 0.885 & 0.494 & -0.567 & 0.904 & 0.868 & 0.597 & 1 & 0.487 & -0.172 \\
\hline $\mathrm{Cl}$ & 0.096 & 0.517 & 0.115 & 0.425 & 0.450 & -0.288 & 0.327 & 0.565 & 0.364 & 0.487 & 1 & 0.601 \\
\hline $\mathrm{NO}_{3}$ & -0.198 & 0.225 & -0.272 & -0.256 & 0.224 & 0.433 & -0.115 & 0.142 & -0.029 & -0.172 & 0.601 & 1 \\
\hline
\end{tabular}

Table A4

Pearson's correlation matrix for the marker concentrations in water extract.

\begin{tabular}{|c|c|c|c|c|}
\hline Variable & $\mathrm{Na}$ & K & $\mathrm{Cl}$ & $\mathrm{NO}_{3}$ \\
\hline $\mathrm{Na}$ & 1 & 0.621 & 0.517 & 0.225 \\
\hline K & 0.621 & 1 & 0.487 & -0.172 \\
\hline $\mathrm{Cl}$ & 0.517 & 0.487 & 1 & 0.601 \\
\hline $\mathrm{NO}_{3}$ & 0.225 & -0.172 & 0.601 & 1 \\
\hline
\end{tabular}

Appendix B

Fig. B1Relationship between $\mathrm{Cl}^{-}$and $\mathrm{Na}^{+}$concentrations in water extracts.

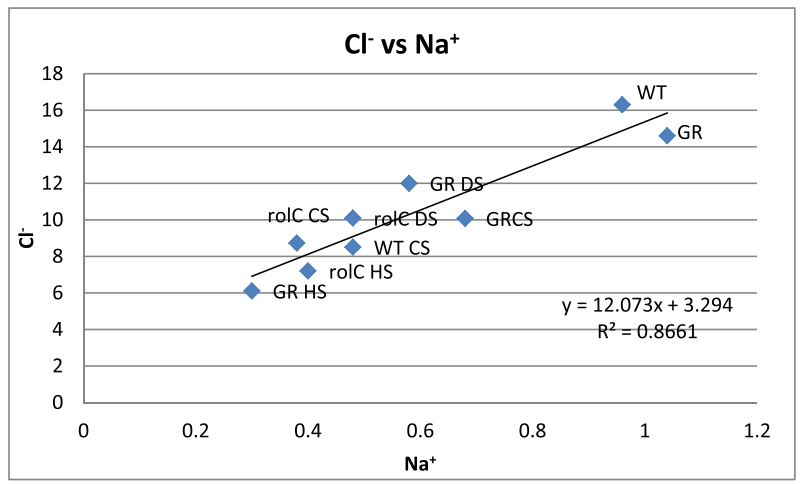




\section{References}

[1] A.B.M. Loitsch, G. Khal, Transcriptional activation of plant defence genes by shortterm air pollutant stress, Environ. Pollut. 89 (1995) 221-227.

[2] I. Cakmak, The role of potassium in alleviating detrimental effects of abiotic stresses in plants, J. Plant Nutr. Soil Sci. 168 (2005) 521-530.

[3] N. Candan, L. Tarhan, The correlation between antioxidant enzyme activities and lipidperoxidation levels in Mentha pulegium organs grown in $\mathrm{Ca}^{2+}, \mathrm{Mg}^{2+}, \mathrm{Cu}^{2+}$, $\mathrm{Zn}^{2+}$ and $\mathrm{Mn}^{2+}$ stress conditions, Plant Sci. 165 (2003) 769-776.

[4] M. Patra, N. Bhowmikb, B. Bandopadhyay, A. Sharma, Comparison of mercury, lead and arsenic with respect to genotoxic effects on plant systems and the development of genetic tolerance, Environ. Exp. Bot. 52 (2004) 199-223.

[5] C. Poschenrieder, R. Tolra, J. Barcelò, Can metals defend plants against biotic stress? Trends Plant Sci. 11 (2006) 288-295.

[6] L. Taiz, E. Zeiger, in: Sinauer Associate (Ed.), Plant Physiol, 2000.

[7] T. Doroszewska, A. Berbeć, Variation for cadmium uptake among Nicotiana species, Genet. Resour. Crop. Evol. 51 (2004) 323-333.

[8] J.L. Hall, Cellular mechanisms for heavy metal detoxification and tolerance, J. Exp. Bot. 53 (2002) 1-11.

[9] B.B. Buchanan, W. Gruissem, R.L. Jones (Eds.),Biochemistry and Molecular Biology of Plants, 2000 (ASPP SYMP P).

[10] P.J. Davies (Ed.), Plant Hormones: Biosynthesis, Signal Transduction, Action! Kluwer Academic, Netherlands, 2004.

[11] M.H. Wang, H. Rhee, Identification and expression of the GTcyc cDNA clone from genetic tumors formed on a Nicotiana glauca-N. langsdorffi hybrid, Plant Physiol. Biochem. 38 (2000) 679-684.

[12] S. Aoki, K. Syohino, The roles of Rirol and Ngrol genes in hairy root induction in $\mathrm{Ni}-$ cotiana debneyi, Plant Sci. 159 (2000) 183-189.

[13] M. Bataung, Z. Xianjin, Y. Guozheng, Z. Xianlong, Review: nitrogen assimilation in crop plants and its affecting factors, Can. J. Plant Sci. 92 (2012) 399-405.

[14] F.E. Bear, Cation and anion relationship in plants and their bearing on crop quality, Agron. J. 42 (1950) 176-178.

[15] M.N. Laus, M. Soccio, D. Trono, M.T. Liberatore, D. Pastore, Activation of the plant mitochondrial potassium channel by free fatty acids and acyl-CoA esters: a possible defence mechanism in the response to hyperosmotic stress, J. Exp. Bot. 62 (2011) $141-154$.

[16] M. Lucarini, L. D'Evoli, S. Tufi, P. Gabrielli, S. Paoletti, S. Di Ferdinando, G. LombardiBoccia, Influence of growing system on nitrate accumulation in two varieties of lettuce and red radicchio of Treviso, J. Sci. Food Agric. 92 (2012) 2796-2799.

[17] R. Fuoco, P. Bogani, G.M. Del Bubba, O. Abollino, S. Giannarelli, M.M. Spiriti, B. Muscatello, S. Doumett, C. Turetta, R. Zangrando, V. Zelano, M. Buiatti, Response to metal stress of Nicotiana langsdorffii plants wild-type and transgenic for the rat glucocorticoid receptor gene, J. Plant Physiol. 170 (2013) 668-675.

[18] M. Del Bubba, C. Ancillotti, L. Checchini, L. Ciofi, D. Fibbi, C. Gonnelli, S. Mosti, Chromium accumulation and changes in plant growth, selected phenolics and sugars of wild type and genetically modified Nicotiana langsdorffii, J. Hazard. Mater. 2 (2013) 394-403.

[19] C. Ancillotti, P. Bogani, S. Biricolti, E. Calistri, L. Checchini, L. Ciofi, L.M. Del Bubba Changes in polyphenol and sugar concentrations in wild type and genetically modified Nicotiana langsdorffii Weinmann in response to water and heat stress, Plant Physiol. Biochem. 97 (2015) 52-61.

[20] E. Scalabrin, M. Radaelli, G. Rizzato, P. Bogani, M. Buiatti, A. Gambaro, G. Capodaglio, Metabolomic analysis of wild and transgenic Nicotiana langsdorffii plants exposed to abiotic stresses: unraveling metabolic responses, Anal. Bioanal. Chem. 407 (2015) 6357-6368.

[21] M. Di Carro, C. Ianni, E. Magi, Determination of terpenoids in plant leaves by GC-MS: development of the method and application to Ocimum basilicum and Nicotiana langsdorffii, Anal. Lett. 46 (2013) 630-639.
[22] F. Ardini, F. Soggia, M.L. Abelmoschi, E. Magi, M. Grotti, Ionomic profiling of Nicotiana langsdorffii wild-type and mutant genotypes exposed to abiotic stresses, Anal. Bioanal. Chem. 405 (2013) 665-677.

[23] S. Giannarelli, B. Muscatello, P. Bogani, M.M. Spiriti, M. Buiatti, R. Fuoco, Comparative determination of some phytohormones in wild-type and genetically modified plants by gas chromatography-mass spectrometry and high-performance liquid chromatography-tandem mass spectrometry, Anal. Biochem. 398 (2010) 60-68.

[24] P. Bogani, E. Calistri, S. Biricolti, M.R. Castiglione, A. Turrini, M. Giovannetti, M. Buiatti, The rat glucocorticoid receptor integration in Nicotiana langsdorffii genome affects plant responses to abiotic stresses and to arbuscular mycorrhizal symbiosis, Plant Biotechnol. Rep. 9 (2015) 209-220.

[25] A. Blum, Use Of PEG to Induce and Control Plant Water Deficit in Experimental Hydroponics' Culture((Plantstress: Tel Aviv) Available online at) http://www. plantstress.com/methods/PEG.htm 20 March 2014.

[26] C.M. van der Weele, W.G. Spollen, R.E. Sharp, T.I. Baskin, Growth of Arabidopsis thaliana seedlings under water deficit studied by control of water potential in nutrient-agar media, J. Exp. Bot. 51 (2000) 1555-1562.

[27] S. De Martin, P. Restani, Determination of nitrates by a novel ion chromatographic method: occurrence in leafy vegetables (organic and conventional) and exposure assessment for Italian consumers, Food Addit. Contam. 20 (2003) 787-792.

[28] P.A. Marshall, V.C. Trenerry, The determination of nitrite and nitrate in foods by capillary ion electrophoresis, Food Chem. 51 (1996) 339-345.

[29] J.T. Woolley, G.P. Hicks, R.H. Hageman, Rapid Determination of Nitrate and Nitrite in Plant Material, 8, 1960 841-842.

[30] S.Y. Chung, J.S. Kim, M. Kim, M.K. Hong, J.O. Lee, C.M. Kim, I.S. Song, Survey of nitrate and nitrite contents of vegetables grown in Korea, Food Addit. Contam. 20 (2003) 621-628.

[31] H.M. Bollons, P.B. Barraclough, Inorganic orthophosphate for diagnosing the phosphorus status of wheat plants. J. Plant Nutr. 20 (1997) 641-655.

[32] O. Abollino, M. Malandrino, A. Giacomino, E. Mentasti, The role of chemometrics in single and sequential extraction assays: a review part I. Extraction procedures, uniand bivariate techniques and multivariate variable reduction techniques for pattern recognition, Anal. Chim. Acta 688 (2011) 104-121.

[33] D.L. Massart, B.G.M. Vandenginste, L.M.C. Buydens, S. De Jono, P.J. Leqy, J. SmeyersVerbeke, Handbook of Chemometrics and Qualimetrics, Parts A and B, Elsevier, Amsterdam, 1997.

[34] R. Munns, Genes and salt tolerance: bringing them together, New Phytol. 167 (2005) 645-663.

[35] P.H. Nam, A. Benitez, F. Hommet, D. Bombe, O. Schoefs, A. Pauss, A new quantitative and low-cost determination method of nitrate in vegetables, based on deconvolution of UV spectra, Talanta 76 (2008) 936-940.

[36] A. Spena, T. Schmulling, C. Koncz, J.S. Schell, Independent and synergistic activity of rolA, B and C loci in stimulating abnormal growth in plants, EMBO J. 6 (1987) 3891-3899.

[37] T. Schmulling, M. Fladung, K. Grossman, J. Schell, Hormonal content and sensitivity of transgenic tobacco and potato plants expressing single rol genes of Agrobacterium rhizogenes, T-DNA, Plant J. 3 (1993) 371-382.

[38] V. Bonhomme, D. Laurain Mattar, M.A. Fliniaux, Effects of the rolC gene on hairy root: induction development and tropane alkaloid production by Atropa belladonna, J. Nat. Prod. 63 (2000) 1249-1252.

[39] E. Frossard, L.M. Condron, A. Oberson, S. Sinaj, J.C. Fardeau, Processes governing phosphorus availability in temperate soils, J. Environ. Qual. 29 (2000) 15-23.

[40] E. Santos, M. Conceição, B.S.M. Montenegro, C. Couto, A.N. Araújo, M. Fernanda Pimentel, V.L. da Silva, Sequential injection analysis of chloride and nitrate in waters with improved accuracy using potentiometric detection, Talanta 63 (2004) 721-727.

[41] P.J. White, M.R. Broadley, D.J. Greenwood, J.P. Hammond, Genetic Modifications to Improve Phosphorus Acquisition by Roots(Proceedings 568) International Fertiliser Society, York, 2005. 